The Brock Review Volume 11 No. 1 (2010)

(C) Brock University

\title{
Racing the Curriculum: Refugee Students and the Rhizomatic Model
}

Anne M. Harris

Victoria University

\begin{abstract}
This article presents and interrogates a series of short films made collaboratively by the researcher and Sudanese young women from refugee backgrounds in Australia. They examine the prevailing social conditions for connectedness/ disconnectedness in the context of a sometimeshostile contemporary immigration climate. The films utilise arts-based methodologies to disrupt the folds and pleats of conventional stories told of and about the pedagogies of belonging and becoming. The films draw upon the informants' social practices of self to trouble teleological narratives of identity and they offer a territory of possibilities for travelling along disorienting lines of flight.
\end{abstract}

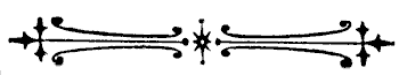

\section{Admitting the Arts-based Truth}

I'm pink and sweaty in my heavy Levi's while cooler, darker others glide by in loose-fitting comfort and good-humoured scorn in long bright dresses under this summer 2008 Melbourne sun. I'm meeting 19-year old Achol Baroch at the central bus station in the multicultural western suburbs of Melbourne, as I prepare to start another film in my series of ethnocinematic documentaries on Sudanese Australian young women and their experiences of education. Achol doesn't know what to expect, and when we meet she is surprised: instead of learning how to film and edit, Achol immediately recognises that I'll be teaching more about the arts-in-education passions of an American-Australian middle-aged lesbian than blazing a dramatic new path in qualitative research using film. She indulges me, and picks up the camera.

"You like Tyra?"

I smile. "Yeah, she's okay."

Mostly the sixteen young women I've worked with don't want to talk about school because they have almost all dropped out or-like Achol—never got there in the first place. Her English language skills weren't strong enough to see her streamed into mainstream school from her language centre, and like many of the co-participants, they have come to this project seeking community, and an audience for their stories. Arts-based pedagogies, both inside and outside of schools, are particularly productive ways of working with students from refugee backgrounds, because they don't depend on language, and there is no clear "teacher." Perhaps this is why Achol (and the others) decided to stay: they could sense the absence of hierarchy in arts-based collaboration, and the smell was sweet.

This interdisciplinary research project, Cross-Marked: Sudanese Australian Young Women Talk Education is an example of the kind of bricolage research ${ }^{1}$ which draws on multiple sources and expresses itself in multiple ways, the kind of arts-based enquiry enhancing educational work in many 
sectors today. But Achol didn't know this that first day we met: she was interested in becoming a celebrity, like Tyra Banks or Halle Berry. And as her film reached completion months later, she was the first to suggest they should be posted on YouTube in order to reach a wider audience: it was she and her peers who hinted at the interdisciplinarity of this work between and among areas like public pedagogy, arts-based enquiry, and always the bricolage.

Other co-participants came to this work for different reasons: the young mothers at the River Nile Learning Centre, Grace Mabor their 'peer-mentor' who was hired to assist from "within" the African-Australian community (as if it were homogeneous), to help the teachers in their work and the students in their engagement. Mostly she ends up translating: not linguistically, but more culturally. Like all of us, she is finding her way. Grace has much to say, but she spends a lot of our three months together helping me to figure out what is happening in this liminal space between the co-participants and myself as researcher.

The films and the filming process, ultimately, (no surprise to ethnographic researchers) became more about our relationship than about education. This is an emerging ethnocinema-an extension of ethnographic documentary which is based on relationship and a shared project for social change, not on a history of observation and categorisation. In ethnocinema, no data is "reliable," and we don't expect it to be. Ethnocinema encourages surprise, enigma, ambiguity and other funny English words. It is transgressive, and its only loyalty is to the mutual awakening of the co-participants in this intercultural collaborative work. In ethnocinema ${ }^{2}$, we all inhabit and move beyond subjectivities that are alternately marginal, powered, and excluded; we actively explore this in the work, and recognise these conundrums as productively challenging the centre.

"You know who you look like?"

"Who?" I say (knowing inside they will say Ellen).

"You know, that girl on TV."

"There are lots of girls on TV."

"That one that wears suits. She's got her own talk show."

"I don't know who you mean," I lie.

"You know. Helen!"

Her classmate is kinder: "Hey, at least she's married to Portia de Rossi. She's hot."

We "dance": I perform my "I'm 'normal' enough to confide in" routine; they repeatedly indicate the ways in which I am marginal. They assert their status of insider/capable, as I confront my status of outsider/befuddled. We negotiate, we collaborate, sometimes we grow friendships and sometimes we don't. This is not what I thought doctoral research would be, but in arts-based enquiry the researcher must make herself vulnerable along with the co-participants, or no true collaboration can occur. These films (and relationships) are enacting the principles of critical pedagogy and are educating (us all) toward social change.

\section{From the Bricolage into the Fire}

From March to December of 2008 I co-created seven short ethnocinematic films with Sudanese Australian young women from refugee backgrounds, exploring their experiences of education in Australia and my experiences of this research. These films grew out of my long history of high school teaching using arts-based methodologies in Harlem (New York), the Central Australian desert town of Alice Springs, and more recently in Melbourne, where the growing population of African Australian former refugees was presenting challenges for schools, and schools were presenting challenges for former refugees. Cross-Marked: Sudanese Young Women Talk Education 
was a collaborative arts-based project which created alternate spaces in which the co-participants and researcher/teacher could reflect on their educational experiences, learn (together) how to use video cameras, to shoot and edit documentary films, and to explore their own notions of becoming as new Australians: we are all immigrants with circuitous routes here. We have co-created these films in an effort to comment on our own evolving pedagogical identities, and to offer advice to the education community on ways of improving our work, of providing effective and equitable educational experiences for former refugees. The seven films in the series are:

- "Neir Chi Puj: Educated Girls" documents the life of Lina Deng, a young Dinka woman who has recently graduated from high school. She encourages schools to create opportunities for African student leaders, and reminds us of the intimidation that many newly arrived students feel in the classroom, which goes beyond English as a Second Language (ESL) frustrations.

- "Chick Chat at the River Nile" is the film co-created by Grace Mabor and the young mothers at River Nile Learning Centre. They are limited by their circumstancesmost would like to return to school but schools are not structured to accommodate small children. The language skills of most of the young women in this film are poor, and they are struggling to find their place.

- "Slowly By Slowly" features Grace Mabor, who candidly discusses her six sisters and both parents who have all graduated from university, and the pressure she feels to succeed. She identifies her mother as the driving force in her life, a woman who is educated but accessible, and who has instilled in her children that education is the key to better lives.

- "Singing Into Language" tells the story of Achol Baroch, a young woman who never made it into mainstream school in Australia. When the film begins, she is attending a TAFE college for language learning, as the teachers at language centre felt her English was not good enough to send her on to secondary school. Achol is lost and frustrated, recognises that her situation is very challenging, and-by film's endgives birth to her first child, Loner. Her film details her program of teaching herself English via the internet, using music videos and song lyrics. She recommends to teachers that they record or videotape lessons in order for new English learners to be able to take these recordings home and learn on their own.

- "In Transit/ion" introduces the viewer to Angelina Aluel Kuol, an ambitious young woman who is completing year 12 and has high hopes for the future. She travels three hours per day to and from school, and still must attend a school with no ESL program or teachers-where she is the only African student in the school. She wants more help academically, but recognises the teachers are limited. Her film explores the logistical challenges of living in distant suburbs of the city, sometimes far from schools, friends and services.

- Nyadol Nyuon's film "Still Waiting" considers the future of the Sudanese Australian community, and the successes awaiting those who are currently working assiduously to "fit in". Nyadol is a young Nuer woman who has just completed a Bachelor of Arts, and plans to work in international law and women's rights. She believes that racism inhibits the capabilities of African students in school and in the wider community, and implores educators to become honest and more pro-active about the sometimes-hostile conditions African students currently face.

- The seventh film in this series, entitled EthnocineME is an autoethnographic document of my own experiences of being a co-participant in this research. Its title 
derives from the practice of ethnocinema and how that emerging practice intersects with an emerging sense of myself. It includes segments of video diary, segments of footage of myself filmed by the Sudanese co-participants, and other visual overlays filmed by the co-participants or their friends, colleagues, family members or passersby. The value of the seventh film in the series is for me as researcher to reflect honestly on my own positionality and my subjective role in helping to create documents that seem to represent individuals or (to some) whole communities and absolute viewpoints. It is to make explicit our shared fugitive knowledges which are not always acknowledged by formal processes like educational institutions or doctoral research projects. In this way I as researcher seek to enter a shared space of selfexamination.

These seven films document the wide spectrum of abilities, ambitions and circumstances encountered by just sixteen young Sudanese women living in Australia today and our experiences of working together, which has sometimes been difficult, not only due to the difficult logistics of lives still engaged in resettlement, but due also to intercultural and cross-generational misunderstandings. My identity as a gay woman, although never discussed directly, impacted my researcher experience, in a shared interrogation of belonging and identity. A 40-something woman who is still "unmarried" and childless elicited discomfort, pity and sometimes derision from these women. I have been advised on fashion, dating, fertility and cooking. I've been asked if I'm jealous of their boyfriends, housekeeping, children and Blackness. I've been ridiculed for emigrating from the United States, and simultaneously had contacts, gifts and airline tickets demanded of me. I've been not only a researcher and filmmaker, but a babysitter, a taxi driver, a social worker, tutor and mentor. I've asked them to share their lives with not only me but also the camera, that unassailable "other" in the unseen audience to whom they speak, and I've had to share my own in return. I've made burgeoning friendships with many of the co-participants, but I've also left our meetings in tears, enraged, screaming the often-two-hour drive back home at the top of my lungs. I've spent days in McDonalds and shopping malls waiting for participants who never materialise. I've worked with over 25 young people and ended up with just seven films. I'm proud of the films, as are the participants, but-like all truly collaborative arts practice - it has been a long and winding road.

\section{Ethnocinema as Bricolage Research}

I opened this paper with a personal reflection on the very subjective process of this filmbased "performative ethnography" in order to highlight and acknowledge the centrality of the autoethnographic aspect of it. ${ }^{3}$ Kincheloe and McLaren remind us, acknowledging Freire's central place in the development of an emerging criticality, that "he insisted on involving, as partners in the research process, the people he studied as subjects" and in which everyone "learned to see more critically, think at a more critical level, and to recognise the forces that subtly shape their lives." ${ }^{4}$ The emerging discipline of ethnocinema extends traditional ethnographic documentary through the nature of the partnership between researchers/artists and co-participants, and rejects the anthropological origins of traditional ethnography. Ethnocinema attempts to go beyond recognising the forces of which Kincheloe and McLaren speak, to using documentary as a tool for radical social change, and acknowledges that this is already being done by many documentarians at work in the $21^{\text {st }}$ century. Further, ethnocinema subordinates aesthetic concerns to processes of collaboration, equity and social change. This paper explores the struggle of Sudanese Australian young women and their attempt to move from refugee pasts to "integrated" Australian futures, my relationship with them as a researcher and co-creator of short films, and of the ever-changing nature of these processes as a 
notion of becoming which is ongoing, shared and multi-layered. Arts-based practices, such as ethnocinema which are interdisciplinary and self-reflexive, allow for this.

Performance ethnography ${ }^{5}$ is compatible with what Denzin and Lincoln, Kincheloe \& Steinberg, and others have articulated as a practice of research bricolage. Denzin tells us this can be an ethnography that "works outward from those moments of existential crisis in the culture" and which affirms each individual's right to be an active agent in the formation of their destiny from the circumstances in which they find themselves. The young women in this study show us repeatedly how active is their agency, if not yet holding the social capital they are striving toward. This is a research process that includes the researcher as an intentional agent of social change, and which "seeks insight from the margins of Western societies and the knowledge and ways of knowing of non-Western peoples." 7 These considerations have implications for planning, executing and understanding the research and which recognise that research with social change at its core is never truly finished. And so it is with Cross-Marked, which may never be finished, because these sixteen young women are continuously changing, growing and challenging themselves and the school (and social) systems that "are shaped by forces that exist behind their backs."

Ethnocinema, in particular, recognises by its' prioritising of relationship in the collaborative process that "existential crises in the culture" are shared: when something is not working, it is damaging for us all, integrated as we are. This includes but is not limited to sites of pedagogy and arts-production. When these two endeavours come together, as in Cross-Marked, all collaborators now have the chance to creatively explore new ways of being, by "producing narratives, metaphors, and images that exercise a powerful pedagogical force over how people think of themselves and their relationship to others."

Ethnocinema recognises the social agency of its creators, who are no longer subject and documentarian, but collaborators in the creative process. These collaborators may be teachers/students or researchers/young people, arts workers/community members or all community members. The elitism of "expertise" evaporates in ethnocinematic collaboration, and all parties contribute dynamically to the art-making. But this is not therapeutic art-making, either: research such as Cross-Marked is not made to "empower" anyone, or to "give" voice to Sudanese Australian young women, in keeping with critical pedagogy's rejection of hierarchies which seek to bestow power or voice to others. They are, instead, co-created "alternative spaces" for knowledge that is crucial for Sudanese Australian young women to speak and for teachers to hear. Their goal is transformation of multiple pedagogical spaces-be they in schools, on streets, or in living rooms. This project reinforces the value of co-participant Achol Baroch's ability to learn English from the internet, just as it wishes school teachers to acknowledge the possibilities inherent in these public spaces. Literacy teaching and learning must move beyond "a technical or credentialized task-it must be seen as a pedagogical practice of both learning and unlearning."

Arts-based projects-both within schools and in research contexts-are perfectly aligned with research bricolage and the notions of multimodal, organic explorations. Cross-Marked celebrates relationships between researchers and co-participants as "always complicated, mercurial, unpredictable, and, of course, complex," (sometimes uncomfortable) conditions because of the rich research, social justice (and sometimes artistic) outcomes possible from such instabilities and troublings. McLaren and Kincheloe encourage researchers like me to abandon advance-planned research strategies that so often only constrict the research, or sabotage it altogether. What emerges can often seem completely unexpected (although, with hindsight, it is not necessarily so), disarmingly personal (as it must be), and both more and less than one originally intended to examine. Cross-Marked has drawn on the methodological approaches of auto/ethnography and arts-based research and the theoretical frameworks of critical pedagogy, notions of Giroux's public pedagogy and research bricolage in order to match the complexity and 
richness of these Sudanese Australian young women's stories and experiences. But it also exemplifies Cormier's notion of rhizomatic models of learning, which encompasses public pedagogies and popular culture. Deleuze \& Guattari articulated their concept of the rhizome in $A$ Thousand Plateaus as "a map that must be produced, constructed, a map that is always detachable, connectable, reversible, modifiable, and has multiple entryways and exits and its own lines of flight," and the act of becoming and shape-shifting exemplifies the process of film creation engaged in by these Sudanese Australian co-participants. ${ }^{12}$ If all learning is negotiated and emerging, if education for former refugees is to be recast as anything other than "deficit model" games of catch-up, pedagogy must be understood and enacted as "always...reversible, modifiable" and occurring simultaneously in multiple sites.

This project highlights the ways in which arts-based tools can be used in pedagogical sites (classrooms and other) to democratise the modes of communication and knowledge acquisition, enriching the experience of all learners (including teachers) grounded in ways of being which run contrary to capital-based, acquisitive western hierarchies (or Freire's "banking system" which typifies students as empty vessels who require "an act of depositing, in which the students are the depositories and the teacher is the depositor"). ${ }^{13}$ The banking system has long-since stopped working, both in the classroom, with curricular knowledge, and in schools or other communities with social knowledge.

Robinson ${ }^{14}$ highlights the limitations of contemporary schools still structured on $19^{\text {th }}$ century models "to meet the needs of industrialism," maintaining hierarchies of subjects which serve to supply universities and the workforce. Those subjects (and students) most suited to maintaining capitalist economies are prioritised, and others are devalued. And yet, there are educational, economic and information revolutions occurring around us. We must alter our practices now to provide multimodal and accessible ways of learning for students like these co-participants who are in many ways ahead of the school system: they are voracious acquirers of knowledge, and they know that schools are often not the best place to find what they need. This work then which grows out of the multiple ways of knowing of former refugees resettling in new Western environments, is both research bricolage (in its ways of understanding and interpreting) and rhizomatic (in its ways of creating knowledge).

\section{Racing the Rhizome}

The principles of research bricolage can be applied to ways of learning, not just researching. These co-participants have shown interdisciplinarity in their approach to acquiring the knowledges they need. From making videos to singing, from dances and dramas to textbook victories, these young women recognize that you take it where you can get it. A multimodal approach, for former refugees, is logical. As Achol suggests:

If a teacher's reading into my ears [in a tape recorded lesson], and I'm following what she's saying here [on the page], that would be easy for me. And then if there's something a little bit harder, I can ask her, but I understand most of whatever she's writing down here, [because] I'm hearing it. And I'm looking at it. There's nothing better than that: you can hear and you're looking at it.

Any new radical pedagogy that is willing to reconsider itself as well as its student-participants must admit to the increasingly capitalist economy of the education system and our vulnerability to it as participants in the system. "The seduction of capital is overwhelming even among the most well- 
intentioned groups of progressive educators," ongoing process of integration, a vital part of this assistance must be to unsettle the seduction of capital itself. This is a radically different kind of assistance than simply helping these young people try and "catch up" - a project which most young former refugees find overwhelming, dispiriting and remarginalising. Based on a deficit view of capitalist participants who are new to the system and lacking in market skills, both the students and their allies become less motivated (not more) in their quest to improve conditions. They are (both former refugee students and their teachers) more than their lack. Achol tells us,

We can't blame everything on teachers. Sometimes it's a little bit hard. If the class have like 20 or 30 students [they] can't know which one to go to. But [they] know which one is weaker, that kinda needs your help a lot more than others. And then you know if you can't go to them all, you take a little bit smarter one, and a little bit learning one, put them together and you got no problem. You mix them all together, if you see someone is a little bit lower down than others, you can take one person and put them with her and say, "Can you help her today? You guys help each other and show me what two of you can do." That way the kid can learn from another person, and the other person can take something from her.

Critical pedagogues welcome scenarios of this kind where students help students, using innovative and creative methods, and teachers facilitate the process. Critical pedagogy encourages students to "produce and appropriate space for the production of fugitive knowledge forms, those forms of knowledge that often exist either outside of the mainstream curriculum or are seen as unworthy of serious attention." ${ }^{16}$ Co-participant Achol suggests that ICT-supported learning and arts practices like film and drama will enhance language learning and democratic classroom practices, and is simple and achievable. She identifies that even within TAFE-based ESL classes, students who are "a little bit lower down" are devalued within classrooms, and that these students have something to share with their peers. Her commentary suggests ways that rhizomatic learning with multiple entry points can help to create more socially just, but also more creative, classroom practices.

Cross-Marked utilises Kincheloe's extension of bricolage to advocate the use of multiple theoretical frameworks in pursuit of complex knowledge construction and to resist more constrictive "monological" modes of research. ${ }^{17}$ Bricolage research and critical pedagogy allows multi-strand sources of knowledge and knowing to inform both educational and subjective experience, and Achol and other co-participants show that their experiences cannot be narrowly defined as "educative", "cultural", "arts-based" or "gendered". In considering ways of working with former refugees, Kincheloe's bricolage and Cormier's rhizome can compatibly be employed in both educational contexts and in research contexts to broaden educationalists' and researchers' understanding of the complex and dynamic process of identity construction that former refugee students are undergoing. Kincheloe asserts that "the multilogicality of the bricolage demands not only new forms of research but undermines the very structure of education as it now exists." "These changes need not be expensive and terrifying. In the first film, Grace recommends treating former refugee students just like everyone else, but with a particular emphasis on talking with them, learning about them, unsettling stereotypes. In the second film Nyadol discusses the dire daily consequences of racism in schools and recommends that teachers begin to acknowledge this racism as an impediment to all learning, instead of "ignoring it". She recommends making films, participating in research, using the 
media itself but above all working with families and communities to keep students in school. Achol recommends recording lessons on video or audio so that students can benefit from repetition without disadvantaging students who don't need the same. She and many of the young women from River Nile Learning Centre advocate the use of music videos, vocabulary books, movies, talk shows, mobile phone texting and internet chatting to improve English language skills. These are all achievable suggestions, but are educators listening?

Cormier and others are developing Deleuze and Guattari's rhizomatic model for education and the information age, ${ }^{19}$ in ways made real by the young women at River Nile Learning Centre and Achol's film commentary. The rhizomatic model offers an extension of knowledge-as-negotiation in a "social as well as a personal knowledge-creation process with mutable goals and constantly negotiated premises."20 Achol, the River Nile students and my Sudanese Australian high school students know only too well that integration and knowledge acquisition are both social and personal, but their experiences (in the arts) also imagine a "public pedagogy that plays a decisive role in producing a diverse cultural sphere that gives new meaning to education as a political force." 21

"Mistaking perception for truth not only reduces our ability to make sense of the world around us but also harms those with the least power to pronounce what is true," 22 and diasporic Sudanese young women in countries around the globe are attempting to articulate what is true as they see it. Research bricolage demands an identification of what is absent and how to bring it back from the "dismissed, deleted and covered up" 23 margins. Kincheloe calls this "boundary work" and identifies that as I bring to the surface that which has been buried, so too do I expose the "ideological devices that have erased the lived worlds and perspectives of those living in the margins of power," ${ }^{24}$ which includes not only Sudanese Australians, but students, teachers and researchers marginalised on the basis of gender, sexuality, ability, race and class. Certainly I can apply this to the lived experiences of young Sudanese Australian students struggling with school culture and attempting to integrate from the margins of power. Importantly, too, I can apply it to myself.

Kumashiro's challenge to develop anti-oppressive educational practices compels us to examine ourselves and our own practices, not the marginalised other: "What if, in other words, we acknowledge that the "problem' is not a lack of diversity, but a resistance to diversity (and an insistence on maintaining certain categories of privilege)?" and that our efforts to redress social injustices then squarely involve "troubling" our practices." 25 To imagine such a new future, or "trouble" our current practices, arts-based approaches offer rich opportunities for exploring that which is not-yet present, in a democratic and co-created manner. It is just such "resistance to diversity", alive and well in schools and also in research, which bears a direct relationship to perceived acts of transgression in the western nations in which they seek to integrate. When African students act confidently and are perceived as aggressive, when gay teachers mentor gay or questioning students and are perceived with suspicion, when racist taunts go ignored, marginalised young people like Achol suffer most:

The hardest thing is trying to imagine who you are and when you're gonna fit in with everybody. If you can't speak English you can't just go along with everybody. You have to try to speak it. That way you can fit in. You know I think I can do more better than this. I can read, write, do a lot of stuff. I know maybe I struggle maybe 3 or 4 or 5 but this one day I'll be maybe better than today. I think I can help other people and appreciate what God gave to me. I came to Australia — other people dream to come here-and some people don't appreciate it, but I do you know. All these dramas going on but...here is more safe, you know yourself, you're safe, you get 
whatever you're looking for, opportunity, everything. That's what is good about it a little bit here.

\section{Refugeity and the Rhizome}

Co-participant Nyadol Nyuon has said that lasting change "can only come from within the community," and that too many resettlement assistance programs (including schools) take a "fractured" approach to assisting former refugees. Schools by their structure then are potentially rich environments in which integrated and ongoing programs can be established and maintained which will assist refugee students and their families as they settle. In secondary schools, on which this research focuses, students often comment on the changing nature of multiple teachers and classrooms, the rapid pace of the curriculum, and the confusion of both students and their families while trying to identify points of contact within the school. Arts-based programs like dance clubs, social clubs, film and art-making projects can provide rhizomatic learning contexts in which multiage and multi-disciplinary mingling can occur, can be entered and exited as needs and abilities dictate. In these environments, students who are still struggling with English language acquisition and acculturation can become leaders, brokers and agents of their own change.

Kumashiro tells us that "common sense does not often tell us that the status quo is quite oppressive," 26 and highlights a lack of teacher training that is anti-oppressive. He challenges us to trouble the very notion of common sense, an obvious and constant endeavour for immigrants, refugees, and those outside the hegemonic constructions of "normal". Kumashiro reminds us that if contemporary education is to create better schools and better societies, we must first recognize the degree to which we are all "outsiders", and become committed to teaching for social justice, or at least for social change. The Cross-Marked project sees an injustice in the inability of teachers to provide authentic, effective schooling for their refugee students, and asks the students themselves to comment upon their ability to learn and the systems which marginalize them and make learning difficult or impossible. This is the kind of critical gaze which I believe is necessary from both students and teachers as we endeavour together to correct the exclusionary practices now evident in many schools. Researchers too must approach education research with a new criticality which acknowledges the understandings these students have, and troubles the presumptions made by their teachers. That is, reframing our own work as co-participant, and the subjects of our research as fellow co-participants.

Cross-Marked suggests that in order to conduct research in refugee education, researchers must contact and reflect upon our own conditions of refugeity as a state of being rather than an identity. $21^{\text {st }}$-century western culture demands that an increase in mobility and media saturation has implications for the way we see ourselves but also the ways in which we engage with others, at an increasingly rapid rate. Schools too are cultures that are changing rapidly and dramatically. McLaren \& Kincheloe remind us that in such changing environments we must acknowledge that "we are all empowered and we are all unempowered, in that we all possess abilities and we are all limited in the attempt to use our abilities." 27 If we as teachers were encouraged to explore our own moments or states of refugeity (that is, of feeling outside, other, fugitive or displaced) the nature of this change could be more self-reflexive, less intimidating, and more welcomed by all. Cross-marked encourages this difficult work, and sees the reflection and action derived from it as a potent way forward in creating truly democratic schools. As McLaren \& Kincheloe point out, critical researchers must now be "cautious in our use of the term "emancipation" because, as many critics have pointed out, no one is ever completely emancipated from the socio-political context that has produced [and is producing] him or her." 28 Cross-Marked recognises these conditions and the need for teachers and 
researchers to change our language, behaviours and engagements around concepts of liberation, education and democracy in our work with-but not limited to-former refugees.

Ethnographic documentarians ${ }^{29}$ have noted that researchers no longer need travel to distant lands to immerse themselves in challenging and remote cultures. Today we find intercultural encounters on our doorsteps, and the role of research appropriately shifts to examining the encounter rather than the other. This is the project identified by an emerging ethnocinema, which understands that contemporary ethnographic film (whether autoethnographic or ethnographic) now must involve critical examination, reflection, and mutual exchange (collaboration) - and that the binarism of Other is anachronistic and unhelpful in the work of radical social change.

Clifford $^{30}$ urges researchers to relinquish the "monological control of the executive writer" 31 and to acknowledge the power imbalance implicit in ethnographic work. Cross-Marked similarly demands of teachers that we must open for discussion the hierarchy of schools and even of student bodies if we are to move forward in ways that acknowledge and nurture the diversity of positionalities present in multicultural classrooms. This includes not only getting real about who comprises our student body, but about ourselves: while we maintain heteronormative school (and research) cultures, we will do little to correct gender, race, sexuality and class prejudices.

To this end, public pedagogy encourages students to "produce and appropriate space for the production of fugitive knowledge forms, those forms of knowledge that often exist either outside of the mainstream curriculum or are seen as unworthy of serious attention." 32 Schools with students from refugee backgrounds, then, are perfectly situated to provide spaces where other ways of knowing can be generated and valued, for the benefit of students and teachers alike. If a tradition of critical pedagogy supposes that educationalists (including students) are by their nature activists in this pursuit of knowledge and transformation, Sudanese Australian young women can be constructed as sitting at the centre of this broad activism. They are by their own admission never far from unsettling the dominant culture, including through their invisibility (as subjective agents), their hypervisibility (through objectification of their colour and height), their silence (as new English language learners), and simultaneously their voices (as Africans, as young people, as women). Their identity construction is by its nature "activist". Not only are they unsettling the dominant cultures in which they find themselves, but they are equally unsettling their home cultures in which they also maintain and re-construct themselves. This is the kind of complex creation of self which McLaren, Kincheloe and others remind us is necessary for creating lasting change within education and in the culture at large.

This kind of cultural production can be considered "a form of education, as it generates knowledge, shapes values, and constructs identity." 33 Giroux's public and cultural pedagogies both acknowledge that ways of seeing are produced in multimodal ways, and are received in multimodal ways. Cultural pedagogy challenges hegemonic forms of knowledge and the agents who produce them. Researchers working in a contemporary, multimodal context therefore require what Denzin and Lincoln's concept of bricolage call "multimethods in conducting and writing contemporary research. Bricolage is metamorphic rock" ${ }^{34}$ in that it contracts and expands; it begs, borrows and steals. Not only does this research explore notions of becoming for the co-participants, it must for the researcher as well. Good qualitative inquiry can do nothing else, but must also include emergent tensions between the researcher's processing of becoming and the co-participants', this "metamorphic/metaphoric rock" of which Vernon speaks. Although we may all share experiences of refugeity, our fugitive knowledges ${ }^{35}$ are not all the same.

The structural change required in this new pedagogy can take some direction from the notion of rhizomatic learning. This is interconnected, open-ended learning for the $21^{\text {st }}$ century and the socalled information age. It is inherently egalitarian due to its constructivist nature, and although student access to internet and other media formats for information distribution is neither equal nor 
truly democratic, it is increasingly so through public access sites, free wireless and user-friendly uploading procedures. Students like Achol may not have home internet access, but she was aware within six weeks of arrival of where she could access it. This access to knowledge preceded by far her English language acquisition, demonstrating as she does in her film that former refugees are no different from other students in effectively finding alternative sources of learning when schools either fail or remain obsolete to students' interests and needs.

The possibilities for bricolage research and rhizomatic learning are perfectly matched by projects such as Cross-Marked, in its desire to expose the various structures shaping the identity construction of women, Africans, lesbians and young people. "Lincoln (2001) maintains that the most important border work between disciplines is taking place in feminism and race-ethnic studies, ${ }^{, 36}$ and the emerging criticality of the $21^{\text {st }}$ century reminds us that these are the absent presences which remain silenced, if strongly felt, in current research and culture. Cross-Marked is one model for an antidote to the slew of "Lost Boys of Sudan" documentary films which sentimentalise an imagined journey from lost to found, which seek to create hierarchies of suffering, validity and reify Rousseau's noble savage in a modern context. The films of Cross-Marked are made by and with ethnocinematic collaborators, and they seek to redress real social injustices within the school system and in our own shared culture which schools mirror. Denzin reminds us that schools are sites of performance and are intrinsically political; it is no longer adequate to limit ourselves to research that seeks "to understand the world"; ${ }^{37}$ we must attempt ethnographies that facilitate political and social change, which can have practical outcomes in a rapidly changing social fabric, which "leads to radical social change." 38

If Cormier uses the rhizome in challenging us to consider the very definitions of knowledge in this rapidly changing social fabric which questions the need for a centre and "experts" in any given field, ${ }^{39}$ the young women of Cross-Marked challenge us similarly. Where Cormier questions the primacy of the canon in educational and academic contexts, the co-participants challenge standard curricula and testing as biased and ideologized measuring tools. In the rhizomatic model, "curriculum is not driven by predefined inputs from experts; it is constructed and negotiated in real time by the contributions of those engaged in the learning process." ${ }^{40}$ ESL students (particularly from refugee backgrounds) know only too well that integration and knowledge acquisition are both social and personal, but their experiences in schools demonstrate encounters where their prior knowledges and active agency are absent. These students find a new kind of freedom online and in their computer spell-checks: there is no racism, the computers never tire, and there is only one student in the infinite classroom of Google.

Students from refugee backgrounds need optimism and persistence, but so too do their teachers. Arts-based and online learning and socialisation programs can effectively draw marginalised students (and importantly their families) back into the life of the school, and provide informal opportunities for language acquisition and socialisation along the way. They can combat racism in ways that schools are not yet doing. But, as these young women's stories remind us, the students have to be in schools in the first place. Critical pedagogy interrogates the economic rationalism seeping into education by asking "What kind of models for identity construction does this new and powerful teaching machine offer? What kind of a better tomorrow does it imply?". "A A rhizomatic learning model, arts-based pedagogy and bricolage research offer all collaborators in the pedagogical project of radical social change innovative and exciting ways forward. In Australia, a better tomorrow is an educational outcome we all desperately need.

NOTE: These films can be viewed at: http://web.mac.com/amharris OR on YouTube by title.

\section{Notes}


${ }^{1}$ Joe L. Kincheloe, "Describing the bricolage: conceptualising a new rigor in qualitative research," Qualitative Inquiry, 7.6 (2001), 679-692.; Joe L. Kincheloe and Kathleen Berry, Rigour and Complexity in Educational Research: Conceptualizing the Bricolage (London: Open University Press, 2004);

${ }^{2}$ Author, Cross-Marked: Sudanese Australian Young Women Talk Education. Unpublished PhD thesis (films and exegesis, 2009).

${ }^{3}$ Norman Denzin, Performance Ethnography: Critical Pedagogy and the Politics of Culture. (Thousand Oaks: Sage, 2003).

${ }^{4}$ Joe L. Kincheloe, and Peter McLaren, "Rethinking Critical Theory and Qualitative Research.” In SAGE Handbook of Qualitative Research, eds. Norman K. Denzin and Yvonna Lincoln (3rd ed., Thousand Oaks: Sage Publications, 2005), 303-342.

${ }^{5}$ Kincheloe \& McLaren 2005.

${ }^{6}$ Norman Denzin, "Interpretive Ethnography." Zeitschrift fur Erriehungswissenschaft 3.3 (2000): 401-409.

${ }^{7}$ Kincheloe \& McLaren, 2005, 318.

${ }^{8}$ Denzin, 2003, xi.

${ }^{9}$ Henry Giroux, "Cultural Studies, public pedagogy, and the responsibility of intellectuals," Communication and Critical/Cultural Studies 1.1 (2004): 62.

${ }^{10}$ Henry Giroux, Border Crossings: Cultural Workers and the Politics of Education (2nd ed.) (New York: Routledge, 2005), 238.

${ }^{11}$ Kincheloe \& McLaren, 2005, 317.

${ }^{12}$ Gilles Deleuze and Felix Guattari, A Thousand Plateaus: Capitalism and Schirophrenia (B. Massumi, Trans.). (London: Continuum, 2004), 23.

${ }^{13}$ Paulo Freire, Pedagogy of the Oppressed (New York: Continuum, 1970), 58.

${ }^{14}$ Ken Robinson, Do schools kill creativity? (Online video) (Monterey, CA: TED, 2006). http://www.ted.com/talks/ken_robinson_says_schools_kill_creativity.html.

${ }^{15}$ Peter McLaren, Che Guevara, Paulo Freire, and the Pedagogy of Revolution (Lanham, MD \& Oxford: Rowman \& Littlefield, 2000, 8.

${ }^{16}$ Henry Giroux, Fugitive Cultures: Race, Violence and Youth (New York: Routledge, 1996), 19.

${ }^{17}$ Kincheloe \& Berry, 2004; Kincheloe \& McLaren, 2005.

${ }^{18}$ Kincheloe \& Berry, 2004, $x$.

${ }^{19}$ Dave Cormier, "Rhizomatic Education: Community as Curriculum," Innovate: Journal of Online Education 4.5 (2008).

${ }^{20}$ Cormier, 2008. Par. 3.

${ }^{21}$ Giroux, 2005, 5.

${ }^{22}$ Karunaratne, 1997, in Kincheloe \& Berry, 2004, 24.

${ }^{23}$ Kincheloe \& Berry, 2004, 20.

${ }^{24}$ Kincheloe \& Berry, 2004, 20.

${ }^{25}$ Kevin Kumashiro, "Queer Students of Color and Antiracist, Antiheterosexist Education: Paradoxes of Identity and Activism," in Troubling Intersections of Race and Sexuality: Queer Student of Color and Anti-Oppressive Education, ed. Kevin Kumashiro (Oxford: Rowman \& Littlefield, 2001),11.

${ }^{26}$ Kevin Kumashiro, Against Common Sense: Teaching and Learning Toward Social Justice (New York: Routledge, 2004), 109.

${ }^{27}$ Kincheloe \& McLaren, 2005, 309.

${ }^{28}$ Kincheloe \& McLaren, 2005, 308. 
${ }^{29}$ Ilisa Barbash and Lucien Taylor, Cross-cultural filmmaking: a handbook, for making documentary and ethnographic films and videos (Berkeley, CA: University of California Press, 1997); David MacDougall, Transcultural Cinema (Princeton NJ: Princeton University Press, 1998).

${ }^{30}$ James Clifford, The Predicament of Culture: Twentieth Century Ethnography, Literature and Art (Cambridge, MA: Harvard University Press, 1988).

${ }^{31}$ Kincheloe \& McLaren, 2005, 326.

${ }^{32}$ Giroux, 1996, 19.

${ }^{33}$ Kincheloe \& McLaren, 2005, 312.

${ }^{34}$ Tanya Vernon, "Beyond Bricolage," in Contemporary Qualitative Research: Exemplars for Science and Mathematics Educators, Vol. 33, eds. P. C. Taylor and J. Wallace (Springer Netherlands, 2007), 205.

${ }^{35}$ Hill, in Giroux, 1996, 216.

${ }^{36}$ Kincheloe \& McLaren, 2005, 317.

${ }^{37}$ Denzin, 2003, 225.

${ }^{38}$ Denzin, 2003, 225.

${ }^{39}$ Cormier, 2008, par. 12.

${ }^{40}$ Cormier, 2008, par. 12.

${ }^{41}$ Juha Suoranta, Tuukka Tomperi, and Robert FitzSimmons, "Revolutionary Pedagogy in Media Culture: Reading the Techno-Capitalist Order of Education," in Critical Theories, Radical Pedagogies, and Global Conflicts, eds. G. E. Fischman, P. McLaren, H. Sunker and C. Lankshear (Lanham, MD: Rowman \& Littlefield, 2004), 195.

\section{Bibliography}

Author, "Cross-Marked: Sudanese Australian Young Women Talk Education" (PhD thesis, films and exegesis, 2009).

Barbash, Ilisa, and Lucien Taylor. Cross-cultural filmmaking: a handbook for making documentary and ethnographic films and videos. Berkeley, CA: University of California Press, 1997.

Clifford, James. The Predicament of Culture: Twentieth Century Ethnography, Literature and Art. Cambridge, MA: Harvard University Press, 1988.

Cormier, Dave. "Rhizomatic Education: Community as Curriculum.” Innovate: Journal of Online Education 4.5 (2008) Nova Southeastern University. http://innovateonline.info/index.php?view=article\&id=550\&action=article.

Deleuze, Gilles, and Felix Guattari. A Thousand Plateaus: Capitalism and Schizophrenia (B. Massumi, Trans.). London: Continuum, 2004.

Denzin, Norman K. "Interpretive Ethnography." Zeitschrift fur Eraiebungswissenschaft 3(3) (2000): 401409.

Denzin, Norman K. Performance Ethnography: Critical Pedagogy and the Politics of Culture. Thousand Oaks: Sage, 2003.

Freire, Paulo. Pedagogy of the Oppressed. New York: Continuum, 1970.

Giroux, Henry. Fugitive Cultures: Race, Violence and Youth. New York: Routledge, 1996.

Giroux, Henry. "Cultural Studies, public pedagogy, and the responsibility of intellectuals." Communication and Critical/ Cultural Studies 1.1 (2004): 59-79.

Giroux, Henry. Border Crossings: Cultural Workers and the Politics of Education (2nd ed.). New York: Routledge, 2005.

Kincheloe, Joe L. "Describing the bricolage: conceptualising a new rigor in qualitative research." Qualitative Inquiry 7.6 (2001): 679-692. 
Kincheloe, Joe, and Kathleen Berry. Rigour and Complexity in Educational Research: Conceptualizing the Bricolage. London: Open University Press, 2004.

Kincheloe, Joe L., and Peter McLaren. "Rethinking Critical Theory and Qualitative Research." In SAGE Handbook of Qualitative Research (3rd ed.), edited by Norman K. Denzin and Yvonna Lincoln, 303-342. Thousand Oaks: Sage Publications, 2005.

Kumashiro, Kevin. "Queer Students of Color and Antiracist, Antiheterosexist Education: Paradoxes of Identity and Activism." In Troubling Intersections of Race and Sexuality: Queer Student of Color and Anti-Oppressive Education, edited by Kevin Kumashiro, 1-26. Oxford: Rowman \& Littlefield, 2001.

Kumashiro, Kevin. Against Common Sense: Teaching and Learning Toward Social Justice. New York: Routledge, 2004.

MacDougall, David. Transcultural Cinema. Princeton NJ: Princeton University Press, 1998.

McLaren, Peter. Che Guevara, Paulo Freire, and the Pedagogy of Revolution. Lanham, MD \& Oxford: Rowman \& Littlefield, 2000.

Robinson, Ken. 2006. Do schools kill creativity? (Online video) Monterey, CA: TED. http://www.ted.com/talks/ken_robinson_says_schools_kill_creativity.html.

Suoranta, Juha, Tuukka Tomperi, and Robert FitzSimmons. "Revolutionary Pedagogy in Media Culture: Reading the Techno-Capitalist Order of Education.” In Critical Theories, Radical Pedagogies, and Global, edited by G. E. Fischman, et al, 185-206. Lanham, MD: Rowman \& Littlefield, 2004.

Vernon, Tanya. "Beyond Bricolage." In Contemporary Qualitative Research: Exemplars for Science and Mathematics Educators, Vol. 33, edited by P. C. Taylor and J. Wallace, 205-216. Springer Netherlands, 2007. 